\title{
Er konsum av melk og egg assosiert med risiko for kreft? Foreløpige resultater fra en prospektiv undersøkelse
}

\author{
Grethe Albrektsen ${ }^{1}$, Ivar Heuch ${ }^{2}$, Bjarne Koster Jacobsen ${ }^{3}$ og Gunnar Kvåle ${ }^{4}$ \\ 1. Seksjon for medisinsk statistikk og dataanalyse, Universitetet i Bergen \\ 2. Matematisk institutt, Universitetet i Bergen \\ 3. Institutt for samfunnsmedisin, Universitetet $i$ Tromsø \\ 4. Senter for internasjonal helse, Universitetet i Bergen \\ Korrespondanse: Grethe Albrektsen, Seksjon for medisinsk statistikk og dataanalyse, Universitetet i Bergen, Armauer Hansens hus, 5021 Bergen \\ Tlf: 55974602 Fax: 55974964 e-mail: grethe.albrektsen@smis.uib.no
}

\begin{abstract}
SAMMENDRAG
Sammenhenger mellom kreftinsidens og konsum av egg og melk er studert i en prospektiv undersøkelse av ca. 50000 personer i alderen 30-69 år. Kostholdsdataene ble samlet inn i forbindelse med andre runde av hjerte- og karundersøkelsene som ble gjennomført av Statens helseundersøkelser i Finnmark, Sogn og Fjordane og Oppland i perioden 1977-83. Gjennomsnittlig oppfølgingstid var 11,8 år. Omlag 2000 personer fikk en kreftdiagnose i løpet av oppfølgingsperioden. Insidensrate-ratioer er beregnet i en log-lineær Poissonregresjon basert på personår under risiko. Vi fant ingen sammenheng mellom total kreftinsidens og konsum av melk (glass pr. dag) eller egg (antall pr. uke), men for spesifikke krefttyper observerte vi enkelte assosiasjoner. Det arbeides nå med mer detaljerte analyser og med internasjonal publisering av resultatene.
\end{abstract}

\section{Albrektsen G, Heuch I, Jacobsen BK, Kvåle G. Is milk and egg consumption associated with cancer risk? Preliminary results from a prospective study. Nor J Epidemiol 1997; 7 (2): 205-208.}

\section{ENGLISH SUMMARY}

Associations between cancer incidence and consumption of milk and eggs were examined in a prospective study of about 50,000 persons aged 30-69 years. The mean follow-up period was 11.8 years. About 2000 persons were diagnosed with cancer during follow-up. Incidence rate ratios were calculated in a log-linear Poisson regression model of person-years at risk. No relations were found between overall cancer incidence and consumption of milk (glasses per day) or eggs (number per week), but some associations were observed for specific sites. The analysis of the data is in progress and the results presented are preliminary.

\section{INNLEDNING}

Det har i mange år vært antatt at kostvaner har betydning for insidens av en rekke av de mest hyppige kreftformene i Norge. Dette gjelder ikke bare kreft i mage-tarm kanalen, men også kreft i lunge, bryst og prostata (1). Høyt fett-inntak har vært foreslått som en mulig risikofaktor for brystkreft, men det er ennå usikkert om det eksisterer en slik sammenheng $(2,3)$. I en studie (4) var høyt melkekonsum assosiert med en redusert risiko for brystkreft. Høyt kalsiuminntak har vært relatert til en svak reduksjon av risikoen for tykktarmskreft (5-7), og A-vitaminer har vært assosiert med en reduksjon i risikoen for lungekreft (8). I en britisk studie som nylig er publisert (9), ble det observert en sterk positiv sammenheng mellom melkeforbruk i slutten av tenårene og risiko for kreft $\mathrm{i}$ testiklene. Det har vært indikasjoner på en sammenheng mellom inntak av egg og øket risiko for kreft i endetarm (10), og daglig inntak av kolesterolholdige matvarer kan gi en svak økning i risikoen for kreft i urinblære (11). Konsum av egg har imidlertid vært relatert til en reduksjon av risikoen for kreft i bukspyttkjertel (12) og galleblære (13).

I andre runde av hjerte- og karundersøkelsene i Finnmark, Sogn og Fjordane og Oppland, som ble gjennomført av Statens helseundersøkelser i perioden 1977-83 (14), ble det samlet inn opplysninger om kosthold. Kostholdsfilen ble koblet med data fra Kreftregisteret og informasjon vedrørende dødelighet 
fra Statistisk sentralbyrå fram til 1993. I et delprosjekt hvor denne kostholdsfilen benyttes til analyser av sammenhenger mellom kostvaner og kreft, har vi studert mulige assosiasjoner mellom kreftinsidens og konsum av melk og egg. Helmelk er en betydelig fettkilde i norsk kosthold. Melk er dessuten en god kalsiumkilde. Egg inneholder mye kolesterol og er også en god kilde til vitamin A og protein. Analyser av sammenhengen mellom kreftrisiko og konsum av melk og egg, vanlige matvarer i det norske kosthold, vil derfor være av interesse. I denne artikkelen vil vi gi en nærmere beskrivelse av datamaterialet som benyttes $i$ analysene, samt presentere en del foreløpige resultater. Prosjektet finansieres av Den Norske Kreftforening.

\section{MATERIALE OG METODE}

Studiepopulasjonen omfatter personer som var 20-56 år ved start av hjerte- og karundersøkelsene (gjennomsnittlig alder var 43,5 år). Hver person ble ansett for å være under risiko for å utvikle kreft fra dato ved undersøkelse, og bidro med personår i påfølgende alderskategorier inntil han/hun fikk en kreftdiagnose, døde, emigrerte, eller studieperioden ble avsluttet (31.12. 1992). Ingen av personene i kohorten ble eldre enn 69 år i løpet av oppfølgingsperioden. Det var relativt få personer under risiko og få krefttilfeller $\mathrm{i}$ alderen 20-29 år. Denne aldersgruppen ble derfor ekskludert i analysene. Vi hadde komplette opplysninger om konsum av melk og egg (og om demografiske variabler) for henholdsvis 49483 og 49502 personer. Disse personene bidro med $5,9 \times 10^{5}$ personår i aldersintervallet 30-69 år. Den gjennomsnittlige oppfølgingsperioden var 11,8 år (variasjonsområde 1 måned til 15,8 år). Av de som hadde fullstendige opplysninger om melkekonsum, var det 1973 personer som fikk en kreftdiagnose i løpet av oppfølgingsperioden, og for de med fullstendige opplysninger om konsum av egg var det 1977 personer som fikk en kreftdiagnose.

\section{STATISTISK ANALYSE}

Sammenheng mellom kreftinsidens og konsum av melk (glass pr. dag) og egg (antall pr. uke) blir analysert $\mathrm{i}$ en log-lineær regresjonsmodell basert på Poissonfordeling. Separate analyser utfores for total kreftinsidens og for ulike kreftformer. Insidensrateratioer justeres for oppnådd alder (30-69 år; 5 års kategorier), fylke, kjønn, og røyking (4 kategorier: ikke-røykere, 1-9, 10-19 og $\geq 20$ sigaretter pr. dag). Tilleggsjusteringer for utdannelse, bosted (by/land), relativ kroppsvekt (BMI) og mosjon er aktuelt for noen kreftformer, og slike analyser vil bli utført før endelige resultater kan presenteres. Generering av personårs-filer og analyse av data ved hjelp av Poissonregresjon blir utført ved bruk av programpakken EPICURE (15).

\section{RESULTATER}

Vi fant ingen sammenheng mellom total kreftrisiko og melkekonsum, eller mellom kreftrisiko og konsum av egg (Tabell 1). Det var likevel indikasjoner på at enkelte kreftformer er assosiert med melkekonsum (Tabell 2; negativ sammenheng med kreft i endetarm, livmor og ovarier, positiv sammenheng med kreft $i$ bukspyttkjertel og skjoldbruskkjertel), og med konsum av egg (Tabell 3; positiv sammenheng med kreft i tykktarm, lunge og livmor). Det gjenstår imidlertid en del analyser med justering for mulig konfundering.

Tabell 1. Insidensrate-ratioer for total $\mathrm{kreft}^{1}$ (IRR med 95\% konfidensintervall) i relasjon til konsum av melk og egg blant personer i alderen 30-69 år.

\begin{tabular}{crrl}
\hline & $\begin{array}{c}\text { Antall } \\
\text { kasus }\end{array}$ & Personår & IRR (95\% KI) \\
\hline Melk (glass pr. dag) & & & \\
$\leq 1$ & 753 & 205819 & 1,00 \\
2 & 555 & 158826 & $0,97(0,87-1,08)$ \\
3 & 342 & 103162 & $1,00(0,88-1,14)$ \\
& 323 & 118092 & $0,90(0,78-1,03)$ \\
& & & \\
Type melk & & & \\
bare helmelk & 1169 & 353541 & 1,00 \\
helmelk/skummet & 291 & 92645 & $0,90(0,79-1,02)$ \\
bare skummet & 427 & 112176 & $1,04(0,93-1,17)$ \\
& & & \\
Egg (antall pr. uke) & & & \\
$<1$ & 461 & 134375 & 1,00 \\
1 & 542 & 173972 & $0,93(0,82-1,05)$ \\
2 & 637 & 179375 & $1,04(0,92-1,17)$ \\
$\geq 3$ & 337 & 98058 & $1,04(0,90-1,20)$ \\
\hline
\end{tabular}

${ }^{1}$ Basert på Poissonregresjon med risikoestimater justert for alder, kjønn, fylke og røyking.

${ }^{2}$ Blant personer som drikker melk.

Tabell 2. Insidensrate-ratioer for utvalgte kreftformer ${ }^{1}$ (IRR med 95\% konfidensintervall) i log-lineær relasjon til konsum av melk blant personer i alderen 30-69 år.

\begin{tabular}{lrr}
\hline & \multicolumn{2}{c}{ Konsum av melk } \\
\cline { 2 - 3 } Lokalisasjon (ICD-7) & $\begin{array}{r}\text { Antall } \\
\text { kasus }\end{array}$ & IRR for lineær trend \\
\hline Totalt & 1973 & $0,98(0,95-1,02)$ \\
Endetarm (154) & 100 & $0,88(0,76-1,02)$ \\
Bukspyttkjertel (157) & 56 & $1,22(1,01-1,47)$ \\
Livmor (172) & 112 & $0,90(0,77-1,06)$ \\
Ovarie (175) & 128 & $0,90(0,78-1,05)$ \\
Skjoldbruskkjertel (194) & 44 & $1,18(0,95-1,48)$ \\
\hline
\end{tabular}

${ }^{1}$ Basert på Poissonregresjon med risikoestimater justert for alder, kjønn, fylke og røyking.

${ }^{2}$ IRR mellom nabokategorier i analyser med inndeling

$<1,1,2,3,4$ og $\geq 5$ glass melk pr. dag. 
$\mathrm{Vi}$ fant heller ingen sammenheng mellom total kreftinsidens og ulike typer melk (helmelk, skummet eller begge deler) blant personer som drakk melk (Tabell 1). Personer som bare drakk skummet melk hadde imidlertid høyere risiko for å få kreft i prostata og benmarg sammenlignet med personer som bare drakk helmelk. Tilleggsjustering for mengde inntak av melk (glass pr. dag) hadde liten innflytelse på risikoestimatene. Sammenhenger mellom ulike kreftformer og mengde konsum av helmelk og skummet melk vil bli studert i separate analyser.

\section{DISKUSJON}

Vi har utført en studie av potensielle sammenhenger mellom kreftinsidens og konsum av melk og egg. Analyse av en og samme kostholdsvariabel i forhold til ulike kreftformer kan gi noe annen informasjon enn undersøkelser av en bestemt kreftform og ulike kostholdsfaktorer. Mulige etiologiske forklaringer som er felles for ulike kreftformer kan lettere bli avslørt, selv om det kan tenkes at samme matvare virker uheldig $\mathrm{i}$ forhold til noen kreftformer og gunstig i forhold til andre. Spesielt for vanlige matvarer som melk og egg er det viktig å avdekke slike effekter. Sammenhenger mellom enkelte kreftformer (kreft i lunge, tykktarm og bryst) og ulike kostholdsfaktorer har tidligere blitt analysert i dette materialet av andre (16-18).

Våre resultater for total kreftinsidens og melkekonsum er i samsvar med resultatene fra en tidligere norsk prospektiv studie (7). Vi arbeider nå med mer detaljerte analyser og internasjonal publisering av resultatene vedrørende sammenhenger mellom konsum av melk og egg og hele spekteret av ulike kreftformer.

Tabell 3. Insidensrate-ratioer for utvalgte kreftformer ${ }^{1}$ (IRR med 95\% konfidensintervall) i log-lineær relasjon til konsum av egg blant personer i alderen 30-69 år.

\begin{tabular}{lrr}
\hline & \multicolumn{2}{c}{ Konsum av egg } \\
\cline { 2 - 3 } Lokalisasjon (ICD-7) & $\begin{array}{r}\text { Antall } \\
\text { kasus }\end{array}$ & IRR for lineær trend \\
\hline Totalt & 1977 & $1,02(0,98-1,07)$ \\
Tykktarm (153) & 174 & $1,11(0,97-1,28)$ \\
Lunge (162) & 183 & $1,09(0,96-1,24)$ \\
Livmor (172) & 112 & $1,23(1,03-1,47)$ \\
\hline
\end{tabular}

${ }^{1}$ Basert på Poissonregresjon med risikoestimater justert for alder, kjønn, fylke og røyking.

${ }^{2}$ IRR mellom nabokategorier i analyser med inndeling $<1,1,2,3-4$ og $\geq 5$ egg pr. uke.

\section{REFERANSER}

1. Doll R, Peto R. The causes of cancer: Quantitative estimates of avoidable risks of cancer in the United States today. J Natl Cancer Inst 1981; 66: 1191-308.

2. Goodwin PJ, Boyd NF. Critical appraisal of the evidence that dietary fat intake is related to breast cancer risk in humans. J Natl Cancer Inst 1987; 79: 473-85.

3. Hunter DJ, Spiegelman D, Adami H-O m.fl. Cohort studies of fat intake and the risk of breast cancer a pooled analysis. $N$ Engl J Med 1996; 334: 356-61.

4. Knekt P, Järvinen R, Seppänen R, Pukkala E, Aromaa A. Intake of dairy products and the risk of breast cancer. Br J Cancer 1996; 73: 687-91.

5. Kearney J, Giovannucci E, Rimm EB m.fl. Calcium, vitamin D, and dairy foods and the occurrence of colon cancer in men. Am J Epidemiol 1996; 143: 907-17.

6. Newmark HK, Wargovich MJ, Bruce WR. Colon cancer and dietary fat, phosphate and calcium: a hypothesis. J Natl Cancer Inst 1984; 72: 1323-5.

7. Ursin G, Bjelke E, Heuch I, Vollset SE. Milk consumption and cancer incidence: a Norwegian prospective study. Br J Cancer 1990; 61: 454-9.

8. Kvåle G, Bjelke E, Gart JJ. Dietary habits and lung cancer risk. Int J Cancer 1983; 31: 397-405.

9. Davies TW, Palmer CR, Ruja E, Lipscombe JM. Adolescent milk, dairy product and fruit consumption and testicular cancer. Br J Cancer 1996; 74: 657-60.

10. Phillips RL, Snowdon DA. Dietary relationships with fatal colorectal cancer among Seventh-Day Adventists. J Natl Cancer Inst 1985; 74: 307-17.

11. Risch HA, Burch JD, Miller AB, Hill GB, Steele R, Howe GR. Dietary factors and the incidence of cancer of the urinary bladder. Am J Epidemiol 1988; 127: 1179-91.

12. Ji BT, Chow WH, Gridley G m.fl. Dietary factors and the risk of pancreatic cancer: a case-control study in Shanghai China. Cancer Epidemiol Biomarkers Prev 1995; 4: 885-93. 
13. Kato-K, Akai S, Tominaga S, Kato I. A case-control study of biliary tract cancer in Niigata Prefecture, Japan. Jpn J Cancer Res 1989; 80: 932-8.

14. National Health Screening Service, Health Services of Finnmark, Sogn and Fjordane, and Oppland counties, Ullevål Hospital, Central Laboratory. The cardiovascular disease study in Norwegian counties. Results from second screening. Oslo: National Health Screening Service, 1988.

15. Preston DL, Lubin JH, Pierce DA, McConney ME. EPICURE - Risk regression and data analysis software. Seattle: Hirosoft International Corporation, 1993.

16. Veierød MB. En prospektiv undersøkelse av sammenhengen mellom kosthold og kreft blant middelaldrende kvinner og menn i Norge 1977-1992. Prosjektbeskrivelse. Norsk Epidemiologi 1997; 7 (Dette nummeret).

17. Gaard M, Tretli S, Løken EB. Dietary factors and the risk of colon cancer: a prospective study of 50,535 Norwegian men and women. Eur J Cancer Prev 1996; 5: 445-54.

18. Gaard M, Tretli S, Løken EB. Dietary fat and the risk of breast cancer: a prospective study of 25,892 Norwegian women. Int J Cancer 1995; 63: 13-7. 